\title{
NO MEIO DESTA PROSA ATUAL, UM POEMA ÉPICO
}

\section{IN THE MIDDLE OF THIS PROSE, AN EPIC POEM}

\begin{abstract}
Antônio Marcos Vieira Sanseverino ${ }^{1}$
Resumo: No presente artigo, o interesse é percorrer as referências à épica na prosa machadiana. O ponto de partida é a atuação crítica de Machado de Assis, chamado a debater as tentativas de poesia épica, principalmente nos anos de 1860. A crônica machadiana incorpora as referências épicas, em termos elevados, para ironizar a precariedade do cotidiano fluminense. No romance e no conto, a referência à épica também se apresenta enquanto ironia a personagens e ações rebaixadas. De certo modo, o crítico aprendeu o campo literário e o lugar da poesia épica no Brasil. O ficcionista, por sua vez, fez uma prosa em que o discurso incorpora os autores da tradição, as cenas e as personagens épicas, mas apenas no vocabulário. Esse descompasso entre cenas e discurso narrativo indica a impossibilidade da ação heroica, revelando uma prosa moderna, que rompe com a tradição épica.
\end{abstract}

Palavras-Chave: Machado de Assis, prosa, épico, ironia.

\begin{abstract}
In this essay, the interest is to study references to the epic in Machado's prose. The starting point is Machado de Assis's critical work about the attempts of epic poetry, especially in the 1860s. Machado's chronicle incorporates epic references, in elevated terms, to mock daily life in Rio. In the novels and short stories, the reference to the epic also appears as an irony of characters and common actions. In a way, the critic learned the literary field and the place of epic poetry in Brazil. The fictionist wrote, for his part, prose in which the discourse incorporates the authors of the tradition, the scenes, and the epic characters, but only in the vocabulary. This mismatch between scenes and narrative discourse indicates the impossibility of heroic action, revealing a modern prose that breaks with epic tradition.
\end{abstract}

Keywords: Machado de Assis, prose, epic, irony.

Hegel define o romance como epopeia burguesa. A partir daí, consagra-se uma leitura do romance como um gênero capaz de representar a realidade em sua totalidade, seja pelo distanciamento, seja por sua construção de um mundo ficcional amplo e complexo. No século XIX, duas questões podem ser interligadas - a pertinência de novas epopéias e a consolidação do romance. A primeira teria a capacidade de representar os heróis nacionais e de contar a história de uma nação. Obra emblemática, o poema épico seria capaz de dar conta da origem do caráter nacional. $\mathrm{O}$ segundo teria origem popular, vinculado à prosa (uma escrita sem o cuidado do verso épico, sem a elevação formal), próximo dos jornais, próximo da produção industrial. Na leitura de tradição hegeliana, o romance tem a potencialidade de cumprir o papel da epopeia. Os critérios de construção e de avaliação, no entanto, mudam para dar conta dessa forma prosaica.

Machado de Assis, crítico atuante e leitor atento da tradição literária, acompanha o surgimento das obras literárias (romance, poesia, teatro). No caso do presente artigo, vamos atentar para o modo como ele analisou a presença do épico na literatura brasileira de sua época. Já tinha ocorrido um debate intenso em torno da publicação de A Confederação dos Tamoios,

\footnotetext{
${ }^{1}$ Universidade Federal do Rio Grande do Sul - UFRGS, Porto Alegre, Rio Grande do Sul, Brasil; https://orcid.org/0000-0001-6085-0881; amvsanseverino@gmail.com
} 
de Gonçalves de Magalhães. José de Alencar atacara a obra por diferentes frentes, mas, no presente texto, cabe salientar a impropriedade da matéria histórica colhida para uma epopeia brasileira. A posterior opção do escritor cearense pelo romance e popularidade de suas obras contribuem para uma tensão entre tentativas de poesia épica e prosa romanesca. Esse debate está presente na obra machadiana. Cabe rastrear o modo como o épico atravessou a prosa ficcional machadiana. Na primeira parte do artigo, retomaremos seu trabalho crítico, quando Machado estuda a produção local. A seguir, analisamos a crônica e, por fim, a ficção em romance e, principalmente, em conto.

\section{Um crítico e a possibilidade da poesia épica}

Em junho de 1866, Machado de Assis observa que a realização de um poema épico é uma fortuna miraculosa. Trata-se de um comentário crítico a partir do surgimento de Colombo, epopeia escrita por Araújo Porto-Alegre. Esse fragmento condensa a problemática a ser analisada no presente texto: o lugar que ocupa o discurso sobre o poema épico na época em que dominam a imprensa, a prosa, o romance.

Um poema épico, no meio desta prosa atual em que vivemos, é uma fortuna miraculosa. Pretendem alguns que o poema épico não é do nosso tempo, e há quem já cavasse uma vasta sepultura para a epopeia e para a tragédia, as duas formas da arte antiga. Não fazemos parte do cortejo fúnebre de Eurípides e Homero. As formas poéticas podem modificar-se com o tempo, e essa é a natureza das manifestações da arte; o tempo, a religião e a índole influem no desenvolvimento das formas poéticas, mas não as aniquilam completamente. (Assis, 2008, p. 1158, grifo meu).

O comentário crítico de Machado de Assis aponta para uma concepção histórica das formas poéticas, que implica permanência (tragédia) e variação temporal (grega, francesa, shakespeariana...). Essa reflexão crítica permite compreender a complexidade de uma reflexão sobre a presença da poesia épica no século XIX.

Em novembro de 1866, Joaquim Serra em carta a Machado de Assis também comenta Colombo, dizendo-se à espera da crítica, de que provavelmente não tomara conhecimento. $\mathrm{O}$ interesse de trazer a palavra desse poeta maranhense é que ele aviva o debate sobre "o desejo dos que ambicionam uma epopeia nacional" (2008, p. 181), principalmente por ver que a epopeia de Porto-Alegre, em dois tomos e quarenta cantos, mais do que uma epopeia, seria de um "simples roteiro de viagem" ou "quase que um drama biográfico" (p. 180). Fala ainda da necessidade de que a "epopeia moderna" deveria buscar uma vereda nova quanto à forma de tratar o maravilhoso.

Em janeiro do mesmo ano, 1866, Machado de Assis, em crítica à Iracema, de José de Alencar, afirma que "as tradições indígenas encerram motivos para epopeias e para éclogas, podem inspirar os seus Homeros e os seus Teócritos" (Assis, 2008, p. 1112). A partir de um argumento histórico, Alencar compôs um poema em prosa para elaborar uma lenda e contar a fundação do Ceará. Há vultos guerreiros, como Poti, mas o poema não envereda pelo épico. Alencar "limita-se a falar do sentimento, vê-se que não pretende sair fora do coração". Se Gonçalves Dias fez opção pela forma épica em I-Juca Pirama, Alencar faz outro uso do argumento histórico, opta pela construção de uma heroína romântica que não "resiste à invasão de um sentimento novo para ela, e que transforma a vestal em mulher" (p.1113). Esses dois exemplos mostram o cuidado de Machado em procurar "ver se o autor atendeu a todas as regras da forma escolhida, se fez obra de arte ou obra de passatempo" (p.1107).

Cabe ainda trazer uma troca de cartas abertas entre Faustino Xavier Novais e Machado de Assis. Em abril de 1868, Faustino faz uma interpelação pública, como fizera antes José de 
Alencar, ${ }^{2}$ e escreve uma carta aberta a Machado sobre um poema épico que fora recém lançado, Riachuelo, tomando como assunto uma das batalhas cruciais na campanha contra o Paraguai. ${ }^{3}$ A carta não apenas aviva o debate sobre o épico, como também elenca poemas que compõem uma tradição em língua portuguesa: Ulisséia, Ulissipo, Caramuru, O Afonso, entre outros. Diz Faustino: "e o poema, no fim de tudo, merecia aceitação mais lisonjeira para o laborioso poeta, que se deu a um trabalho árido e fatigante para coligir dados" (2008, p. 244). Na resposta, depois de longa introdução, Machado diz que o autor enfrentou as dificuldades da épica, fez uso da oitava rima, tinha muitos defeitos que não apagavam o seu valor e, por fim, exalta a grande qualidade da obra, a sinceridade: "Tem este livro uma qualidade valiosíssima - é sincero; respira de princípio a fim a emoção do poeta, o entusiasmo de que ele está possuído".

Nesse curioso debate, ficam patentes a atenção e o estudo que Machado de Assis dedica à forma épica. Demonstra o conhecimento imprescindível da tradição épica, lida com cuidado, mas esse gesto vem junto com o questionamento da possibilidade da epopeia na modernidade. Machado não nega a validade ou a permanência do épico, mas mostra como sua forma se transforma ao longo do tempo. Em outros termos, um poema épico, escrito no Brasil durante século XIX, deveria incorporar as transformações advindas com a modernidade e interrogar as condições locais para uma epopeia nacional. Ao fazer a releitura da obra crítica de Machado de Assis, é possível observar a referência recorrente e difusa à tradição como base para análise da poesia, do teatro e da narrativa de sua época.

Em 1875, Machado de Assis, em Americanas, constrói uma obra com diversos poemas narrativos. Alguns deles, como Potira, ambicionam uma dimensão épica, que dialoga com a tradição ocidental (Ariosto) e com local (Gonçalves Dias). A análise desta obra não será empreendida aqui, mas ajuda a perceber como o debate crítico dialoga com a criação literária machadiana. Em 1870, Luís Guimarães critica a falta de coisas brasileiras em Falenas. De certo modo, "Notícia do estado atual da literatura brasileira" (1873) e Americanas podem ser lidas não apenas como resposta ao crítico, mas principalmente como um esforço para lidar com a transformação da literatura, e da poesia narrativa, nas condições brasileira (de seu lugar) e moderna (de seu tempo).

\section{O cronista, entre historiador de quinze dias e baleiro}

Na Ilustração Brasileira, entre 1876 e 1878, Machado de Assis publicou quarenta crônicas. São as Histórias de quinze dias, em que, sob o pseudônimo de Manassés, Machado escrevia sua intervenção no cotidiano brasileiro, mediado muitas vezes pelas informações do jornal. Nessa série, ele constrói o diálogo entre duas vizinhas, falando do calor, depois do vizinho, como sendo a origem da crônica, como uma conversa trivial e cotidiana sobre a vida alheia. Ao mesmo tempo, é mais do que isso, é uma intervenção na atualidade.

O que é específico na crônica, pois, é a natureza de sua indeterminação. Sua particular ligação ao tempo vivido, como mostrou Machado de Assis na caracterização de suas origens, faz com que dependa dos acontecimentos com os quais busca interagir, movendo-se e transformando-se de acordo com eles. (...) o cronista está sempre sujeito ao imponderável do cotidiano. (Chalhoub; Neves; Pereira, 2005, p. 15)

\footnotetext{
${ }^{2}$ No início de 1868 , José de Alencar escrevera também uma carta aberta apresentando Castro Alves e demandando uma avaliação de Machado de Assis, em relação à qualidade de Gonzaga. "O Senhor foi o único de nossos modernos escritores, que se dedicou à cultura dessa difícil ciência que se chama a crítica. Uma porção do talento que recebeu da natureza, em vez de aproveitá-lo em criações próprias, não duvidou aplicá-lo a formar o gosto e desenvolver a literatura pátria." (Alencar, in Assis, 2008, p. 130)

${ }^{3}$ Vale ressaltar que não existe distância história da matéria escolhida, considerando que a batalha fora recente e, mais do que isso, a guerra ainda não havia se encerrado. Mesmo que o tema seja a guerra e o feito guerreiro, matéria elevada pela forma do épico, mas sem a organização típica de uma epopeia.
} 
Na crônica, um gênero em consolidação no Segundo Império, temos um espaço de experimentação na imprensa, sujeita às pressões dos prazos, o que leva à indeterminação formal. Para alguém tão cioso em apreender as regras de cada gênero, interessa atentar para o modo como Machado de Assis atua. Ele faz uso do pseudônimo, Manassés, filho de José do Egito, aquele que faz esquecer, para se colocar como um historiador de quinzena, com um olhar deslocado do cotidiano. Nas Histórias de quinze dias, há um processo similar. Machado de Assis relê uma notícia em chave épica como se vê no exemplo seguinte. Vereadores de uma câmara municipal foram suspensos por se locupletarem com o dinheiro público. Na mesma noite, a câmara foi invadida e os documentos que poderiam provar o crime, queimados. Daí o cronista, contra a maioria da opinião, chama os vereadores de épicos, que "foram direto a Tróia, armados em guerra" (p. 137).

Na mesma série, Machado de Assis volta a parodiar a poesia épica:

Tocou a vez a Rocambole. Este herói, vendo arrasado o palácio de Príamo e desfeitos os moinhos da Mancha, lançou mão do que lhe restava e fez-se herói de polícia, pôs-se a lutar com o código e o senso-comum.

O século é prático, esperto e censurável; seu herói deve ter feições consoantes a estas qualidades de bom cunho. E porque a epopéia pede algum maravilhoso, Rocambole fez-se inverossímil; morre, vive, cai, barafusta, some-se, tal qual como um capoeira em dia de procissão.

Veja o leitor, se não há um fio secreto que liga os quatro heróis. É certo que é grande a distância entre o herói de Homero e o de Ponson de Terrail, entre Tróia e o xilindró. Mas é questão de ponto de vista. Os olhos são outros; outro é o quadro; mas a admiração é a mesma, e igualmente merecida. (Assis, 2009, p. 157, grifo meu).

Esta é a parte II da crônica de 15 de janeiro de 1877, e, como destaca Sá Rego (1989), está ironicamente caracterizado o herói de nossa época. Manassés declara não ter lido nada além dos comentários, mesmo assim acha que Rocambole seria uma personagem superior a nós, com capacidade extraordinária e admirável, teria tudo para sintetizar os valores que definiriam nossa época. Seria o nosso mediador entre cotidiano e valores universais. O humor corrói, no entanto, a afirmação. Percebemos isto nos termos usados, como xilindró, barafusta, pelo símile capoeira em dia de procissão. Ainda cabe ressaltar a ênfase dada pelo cronista na linhagem que une Aquiles, Enéias, Dom Quixote e... Rocambole, através da admiração dos leitores acentuando que o traço maravilhoso da epopeia se transformou em inverossimilhança. Na seleção dos autores citados, em ordem cronológica (Homero, Virgílio, Cervantes e Ponson de Terrail), há uma passagem do verso épico para a prosa romanesca. Cervantes se inscreve na ordem de uma releitura dos romances de cavalaria, marcado pelo isolamento da personagem central. Com Rocambole, de Terrail, entraríamos na ordem de um romance de aventura, trivializado pelo folhetim, em que a prosa romanesca incorpora o discurso da imprensa. Na dimensão cômica, a crônica insere o romance como uma continuidade do épico, como uma ruptura da forma poética, que pode levar à perda mesma do heroico. Vale ressaltar ainda que se trata de um herói de nossa época, do tempo presente. Sem marcas nacionais, Rocambole seria o herói da civilização burguesa.

Na parte III desta crônica, supressão do estômago, comenta-se um reclame publicitário de alguém que diz ter inventado uma panaceia substituta do estômago. O cronista entra, então, em cogitações a respeito da panaceia que substituiria o cérebro, livrando-nos da árdua tarefa de pensar. São associados, então, a subliteratura da época (que não precisa ser lida para ser conhecida) e o anúncio publicitário enganoso (que elimina a necessidade de digerir). Rocambole seria o herói inverossímil, a panaceia que viria a preencher o vazio de sua época, 
carente de heróis, carente de ideais críveis. Pelo humor, inverte-se o sentido e se coloca a impossibilidade de um herói épico, de uma síntese entre o universal e o particular. Pela associação do jornal, a narrativa épica adquire a mesma falsidade de um anúncio publicitário, em que se promete o impossível.

Ao falar da experimentação formal, é incontornável a referência ao ano de 1878, às publicações de Machado de Assis no jornal O Cruzeiro. Ao lado das "fantasias", textos que escapavam a definição precisa de gênero, Machado adotou o pseudônimo Eleazar para escrever a seção de crônicas Notas semanais, que foram de junho a dezembro de 1878 . Num comentário acerbo sobre a realidade nacional, o cronista faz uso de um experiência formal radical. Lúcia Granja e John Gledson, no estudo introdutório, definem a estratégia compositiva da série: "se a história verdadeira não pode ser contada, ele ressalta o fato ao contar outro obviamente falso, em que sua ironia é plenamente exercida, particularmente na justaposição entre Roma e Macaúbas" (Gledson, Granja, 2009, p. 52). Como os dois comentadores mostram, a ficcionalização é usada na crônica como forma de tornar o cotidiano fluminense, e mais particularmente as incongruências cômicas, tal como o nivelamento de Roma e Macaúbas. Esse é um aspecto importante para se pensar como a crônica fez o discurso épico descer no chão fluminense.

O mesmo gesto identificado pelos críticos é estudado por Roberto Schwarz (2012), quando analisa uma crônica de A semana, em que o cronista retoma a história de Lucrécia para analisar uma notícia de jornal. Trata-se de Martinha que matou João Limeira, que ameaçou violentá-la: “'Não se aproxime, que eu lhe furo'. João Limeira aproximou-se, ela deu-lhe uma punhalada, que o matou instantaneamente." O cronista compara o modo como as duas mulheres defenderam sua honra, mostra que o destino de Lucrécia ganha as páginas da história, enquanto o de Martinha caminha para o esquecimento. Schwarz faz uma análise da crônica para mostrar a necessidade de se levar em conta a matéria brasileira para uma leitura crítica de Machado de Assis. Aponta como o narrador cronista encena o mal-estar do intelectual brasileiro, que faz uso da tradição ocidental para incorporar a matéria periférica, mas, ao fazê-lo, desqualifica essa mesma matéria.

A partir de 1883, Machado de Assis passou a participar de outro projeto, agora coletivo, em que diferentes cronistas ocupavam quase diariamente um espaço da Gazeta de Notícias, sob o nome de Balas de estalo. Machado adotou o pseudônimo de Lélio. Em 15 de julho de 1883, é publicada uma de suas crônicas mais marcantes.

Está achada a epopeia burguesa. Não confundam com a tragédia burguesa; essa está achada há muito. Refiro-me à epopeia, o mais difícil, porque o heroísmo na vida pacata do século não era a mesma coisa fácil de aparecer. E apareceu; e aqui o tenho nas mãos, nestas poucas linhas que os jornais acabam de imprimir e divulgar:

\section{ATENÇÃO}

“Ontem o Sr. José Mendes de Abranches comprou-me objetos no valor de $60 \$ 000$.

"Por lapso de soma, porém somente cobrei $50 \$ 00$, por cujo motivo o dito $\mathrm{Sr}$. Abranches, conhecendo o meu logro, veio horas depois dar-me os $10 \$$ que de menos eu havia recebido. Um ato de tanta probidade não merece ser esquecido, por isso assim o faço público. - O dono da Camisaria Especial, Ed. Sriber, Rua dos Ourives n. 51, porta imensa, corte."

Vejam bem o sentimento poético e a insinuação do Sr. Sriber: "Um ato de tanta probidade não merece ser esquecido". Isto e convidar os Homeros da localidade é a mesma coisa; portanto, acudo com o meu esboço de poesia, que porei em verso, se merecer a animação da crítica. 


\section{CANTO I}

Musa, canta a probidade de Abranches, escrupuloso nas contas, exato nos pagamentos. Que as trompas do século repitam aos séculos futuros este lance extraordinário.

(...)

\section{CANTO II}

A Camisaria Especial é o ponto do universo onde os trocos, quando são demais, não são restituídos ao dono da casa. $\mathrm{O}$ camiseiro põe todo o cuidado em contar o dinheiro; conta, reconta, soma, diminui, multiplica, divide, unta cuspe nos dedos para não perder nada; é o seu método. (...)

\section{CANTO III}

Mas o Abranches não quer só camisas, quer também colarinhos e punhos. Paciente como Penélope, o Camiseiro sobe e desce a escada, para servir o herói. Este inclina-se, palpa, examina, inquire e compra; enfim o Camiseiro diz-lhe o preço. Abranches, econômico, regateia; depois, manda embrulhar tudo. (...)

Então, o deus Cálculo chama um dos seus Erros, e diz-lhe; "Vai, vai ao Camiseiro da rua dos Ourives, e faz com que ele se atrapalhe na conta". O Erro, fiel à ordem, desce, entra na loja, e atrapalha o Camiseiro, que em vez de dar ao herói trinta e dois mil réis, entrega-lhe quarenta e dois. Nem ele adverte o engano, nem o Abranches conta o dinheiro; pega das camisas, colarinho e punhos, cumprimenta e sai.

\section{CANTO IV}

Entretanto, a Probidade, amiga do Abranches, vê a aleivosia, e pensa em salvar o herói. "Não, brada ela; isto não pode ficar assim; é preciso um exemplo grande, raro, nobre, épico; é preciso que o Abranches restitua os dez mil réis".

$\mathrm{E}$, tomando a figura de uma viúva pobre, aguarda o Abranches no corredor da casa deste; mal o vê entrar, lança-se-lhe aos pés. "Divino Abranches, sou uma viúva desvalida; dá-me de esmola o que te sobrar do troco que recebeste". O herói sorri; como pode sobrar alguma coisa do troco? Dócil, entretanto, saca o receptáculo, descinta-o, conta, reconta; é verdade, dez mil réis de mais. Então a deusa: "Em vez de os dares a mim, vai restituí-los ao Camiseiro". E, súbito, desapareceu no ar. Abranches reconhece o prodígio; algum deus benéfico lhe falou por aquela boca. Depositada a caixa em casa, e, rápido como um raio de Febo, voa à Camisaria Especial.

O Camiseiro, encostado ao balcão, refletia na estrada do Madeira e Mamoré, quando o Abranches lhe apareceu, dizendo que vinha restituir-lhe dez mil réis, que recebera de mais. O Camiseiro não acreditou; deu de ombros, riu, bateu-lhe na barriga, perguntou-lhe como ia da tosse; mas o herói teimou tanto, que ele começou a desconfiar alguma coisa; examina a caixa e reconhece que lhe faltam dez mil réis. A preciosa nota é recebida como o filho pródigo; o Camiseiro beija-a, enche-a de lágrimas. O Abranches, comovido pela própria grandeza, deixa a Camisaria, e, teso, alucinado pelo albor de uma consciência imaculada e augusta, caminha impávido na direção da posteridade e da glória eterna. (Assis, 1998, p. 40-43, grifo meu)

O cronista afirma ter encontrado a matéria da "epopeia burguesa", a probidade de Abranches, marca do heroísmo da vida pacata. Seu ponto de partida foi um apedido publicado pelo dono da Camisaria Sriber que quis exaltar a honestidade de um cliente que lhe devolveu o 
troco. Machado de Assis escreve, então, a crônica citada que lhe rendeu resposta indignada do camiseiro e virou motivo de piada entre os baleiros, uma marca de Lélio. Cernic Ramos mostra que a indignação de Sriber e o efeito dessa crônica foi tal, que Lélio passou a ser reconhecido pela história de Abranches.

$\mathrm{Na}$ abertura, vem o anúncio da epopeia burguesa para cantar o "heroísmo da vida pacata" e, a seguir, a transcrição da nota de Sriber que torna público o gesto de Abranches, que volta para devolver o dinheiro recebido a mais, um "ato de tanta probidade que não merece ser esquecido". Está aí a matéria épica, um acontecimento elevado e histórico, um grande feito a ser lembrado pelo poeta, cantado para comunidade. O "Homero da localidade" faz o primeiro ensaio. Vale observar o comentário de Lélio, que espera a recepção da crítica para pôr ou não a história em versos. A partir daí vêm os quatro cantos, escritos em prosa. É possível reconhecer o cotidiano urbano, de uma cidade moderna, ainda que precária, mas a linguagem usada é elevada. Os deuses estão integrados ao cotidiano e disputam entre si. O deus "Cálculo" chama "Erros" para que Sriber erre no troco e dê 10 mil reis a mais para o Abranches. Do outro lado, a Probidade toma a forma de uma viúva, esmoleira, para salvar a probidade de Abranches. Ao final, ele volta à Camisaria Sriber para devolver o dinheiro. Como aparecia nas Notas semanais, a crônica escapa do mero registro cotidiano para a imaginação. Para comentar a modernidade burguesa - cálculo, negócio, cotidiano miúdo -, a crônica narra em tom épico ações triviais, desprovidas de aventura, e o grande feito se reverte em troco miúdo.

Machado de Assis incorpora um debate próprio do século XIX que se apresenta na estética hegeliana. Hegel, em Curso de Estética, colocou que o romance é "moderna epopeia burguesa" (2004, p. 147). Também Georg Lukács, em A teoria do romance (2000), parte de definição similar: "O romance é a epopeia de uma era para a qual a totalidade extensiva da vida não é mais dada como evidente" (p. 55). O herói torna-se problemático, irônico e melancólico, de psicologia demonizada, e traz as marcas do conflito do intelectual da época, um tempo sem deuses. Erich Auerbach (1987), por sua vez, articula a matéria comum do cotidiano à representação séria, através de um estilo misturado. Para ele, o foco está posto na seriedade, que abre espaço para o grande feito e para o trágico de homens comuns, não apenas os nobres ou a camada senhoril.

Na crônica de Machado, ecoa o debate crítico dos anos de 1860 e 1870, em que a possibilidade do épico é posta em questão. Em chave irônica, ele faz com que o épico se transforme em aventura, no romance industrial, esvaziando a possibilidade de representar seriamente uma síntese de valores da comunidade. Aqui, no gesto de Abranches, o dinheiro miúdo, o troco de 10 mil réis, passa a ser o índice da honestidade, o valor a ser celebrado. De tal modo, o anúncio é rebaixado em cada um dos quatro "cantos", escritos em prosa, em que se evidencia o vazio da vida rotineira, a trivialidade do negócio e a falta de matéria épica. $\mathrm{O}$ movimento é o oposto do romance, que devolve a aventura ao cotidiano urbano e aburguesado, há aí uma busca por valores de qualidade e por uma identidade plena, seja através do amor ou da honra, numa luta revolucionária. Na crônica machadiana, debruçada no cotidiano da cidade, o movimento é o contrário, o de mostrar a ausência de luta para o épico e para a honra.

Essa incorporação paródica do épico na crônica não permite definir a posição de Machado de Assis a respeito da possibilidade de uma poesia épica. Assim como sua produção crítica dos anos de 1860 e 1870, a crônica permite observar a complexidade moderna da literatura do século XIX, em que diversas formas literárias convivem, disputam entre si e se definem pela tensão entre elas. De certo modo, até aqui, podemos observar o quanto a reflexão sobre o discurso épico, pelo menos em Machado de Assis, demanda um diálogo com as outras formas literárias com que convive. 


\section{Restos de uma epopeia negativa e uma coleção de várias histórias sem data}

Regina Zilberman (2012), em uma leitura de Memórias Póstumas de Brás Cubas, mostra o quanto Machado de Assis incorporou e subverteu o motivo da viagem. Mais especificamente, Brás Cubas se mostra o avesso de Eneias, herói fundador de cidades, capaz de colocar sua missão acima dos amores por Dido. A força ética, exemplar do herói, leva a escolhas que definem uma finalidade para as ações. Brás Cubas, o menino diabo, se entrega à própria satisfação imediata. Há uma dimensão enciclopédica, incorporada pela inversão paródica e rebaixada. Podemos citar como exemplos a abertura da Eneida que aparece escrita pelo personagem, Arma virunque cano, e A divina Comédia que percorre o enredo do romance em remissões várias, como uma nova forma de conceber o mundo dos mortos, que passa de Hades a Inferno. Quanto ao romance, poderíamos citar inúmeras marcas da presença épica na prosa machadiana, mas vamos encerrar o ciclo da referência épica, e dantesca, com Esaú e Jacó, em que o narrador externo incorpora como epígrafe de seu livro a citação de Aires: Dico que quando l'anima mal nata... Ou ainda, o nexo feito pelo mesmo Aires entre os heróis homéricos e os gêmeos: Paulo, enquanto Aquiles; Pedro, enquanto Ulisses.

De certo modo, a prosa romanesca, para Machado, assume a tarefa de articular a dimensão épica de compor uma totalidade extensiva, em que o herói sintetiza os traços exemplares de uma comunidade, de tal modo que a história e a ficção se cruzam na composição desse herói fundador. Brás Cubas traz essas marcas de herói fundacional em chave rebaixada (Zilberman, 2012). Ao mesmo tempo, a decomposição do cadáver, a falsificação da origem familiar pelo pai, a fragilidade ética, a submissão os desejos imediatos e a falta de propósito são alguns, entre outros traços, que mostram que Machado tomou a matéria de seu tempo e de seu lugar para mostrar a impossibilidade do épico, a não ser como farsa.

É possível dizer que Machado de Assis renuncia à ambição épica de uma representação totalizante da realidade? De certo modo, a crítica faz um deslocamento para a alegoria, ou figurativo (quando Brás Cubas passa a ser uma imagem do Brasil ou um herói fundacional), ou para um princípio formal (a volubilidade do narrador). Especificamente, no segundo caso, na leitura de Roberto Schwarz há um desvendamento da dicção do narrador, a partir de sua dimensão de classe. Brás Cubas, parte da elite escravocrata, traz para seu discurso e para o modo como representa a si e aos outros as marcas do senhor de escravos, com fumos civilizados e citações eruditas que o colocariam em diálogo com a tradição ocidental. O nó da questão, no entanto, é que se o romance se fragmenta, então, as partes não se integram a uma totalidade. Seria importante observar os princípios de desagregação dessa ambição épica.

Nos contos, há remissões óbvias à linguagem épica, como a abertura de "Capítulo dos Chapéus", "Musa, canta o despeito de Mariana, esposa do bacharel Conrado Seabra, naquela manhã de abril de 1879". O enfrentamento com o marido leva Mariana a sair de casa. Guiada por Sofia, percorre as ruas da cidade, é tentada pelo encontro com o ex-namorado numa sala de espera, vai à Câmara dos Deputados e volta para casa, resoluta a manter tudo como estava. Essa síntese sumaríssima mostra a ambivalência dessa narrativa breve. De um lado, a matéria trivial e cotidiana seria inválida para a dimensão épica. E, além da personagem não ter estatura, ao escolher a mediania, o narrador adota uma linguagem que revela a distância entre o estilo elevado e o discurso narrativo das trivialidades. Ao mesmo tempo, o conto revela uma esfera da vida feminina, uma potência que se deixa entrever e que se mostra desprezada pelo marido.

Além dessa, há inúmeras referências à tradição épica: autores (Homero, Virgílio, Dante, Torquato Tasso, Camões...); personagens heroicas (Ulisses, Aquiles, Eneias, Cacambo, Dante...); a passagens marcantes. O procedimento de citação varia de acordo com a posição do narrador do conto, mas predomina o tom cômico, a inversão da seriedade épica. Na releitura feita até aqui, a feição séria é atravessada por algum tipo de ironia, que vai se tornando mais e 
mais corrosiva. O humor irônico atravessa as narrativas e marca a impossibilidade de que os contos pudessem apresentar um fragmento épico, um gesto que fosse de elevação.

Georg Lukács caracteriza o herói romanesco como problemático, alguém isolado que busca um sentido que lhe escapa na vida prosaica. Há uma discrepância entre o ideal subjetivo e o mundo de sua ação. Essa cisão aparece na contística de Machado, implicando o problema da falta de dignidade da ação. O gesto não revela a visão da personagem, a ação mascara uma intenção que lhe fica oculta. Quando o gesto se torna expressão de sinceridade, quando se eleva para além do comum, aproxima-se da insanidade e do isolamento social.

Vejamos uma personagem comum, Rangel, protagonista do conto $O$ diplomático, com narrador heterodiegético. In media res, o conto abre com o Rangel lendo as sortes durante uma festa junina, na casa de um escrivão de cartório. São vaticínios de um futuro incerto! O narrador apresenta a história pregressa desse funcionário de 41 anos, copista, que ambicionou um casamento acima de sua classe e acabou solteiro, acanhado.

Era solteiro, por obra das circunstâncias, não de vocação. Em rapaz teve alguns namoricos de esquina, mas com o tempo apareceu-lhe a comichão das grandezas, e foi isto que lhe prolongou o celibato até os quarenta e um anos, em que o vemos. Cobiçava alguma noiva superior a ele e à roda em que vivia, e gastou o tempo em esperá-la. (...) Também era certo no saguão do paço imperial, em dia de cortejo, para ver entrar as grandes damas e as pessoas da corte, ministros, generais, diplomatas, desembargadores, e conhecia tudo e todos, pessoas e carruagens. Voltava da festa e do cortejo, como voltava do baile, impetuoso, ardente, capaz de arrebatar de um lance a palma da fortuna.

O pior é que entre a espiga e a mão há o tal muro do poeta, e o Rangel não era homem de saltar muros. De imaginação fazia tudo, raptava mulheres e destruía cidades. Mais de uma vez foi, consigo mesmo, ministro de Estado, e fartou-se de cortesias e decretos. (...) Cá fora, porém, todas as suas proezas eram fábulas. Na realidade, era pacato e discreto. (Assis, 2004, p. 163, grifo meu).

O conto começa em media res, numa noite de São João de 1854, quando lia a sorte para as moças da festa. O narrador interrompe a narrativa para apresentá-lo. Um homem com vocação para o casamento, ainda solteiro aos 41 anos, Rangel "de imaginação fazia tudo", mas era incapaz de saltar o muro que o separava do objeto desejado. Nessa noite de 1854, sua esperança se volta para Joaninha, filha da casa, para quem escreve uma carta. Este é o dia da ação. Da revelação de seus afetos. Rangel luta consigo mesmo para entregar sua declaração à jovem, mas não consegue vencer o pudor. Chega na festa Queirós, um jovem empregado da Santa Casa, que passa a cortejar Joaninha. Rangel é derrotado por Queirós. Ao final,

Só consigo, foi-se-lhe o aparelho da afetação, e já não era o diplomático, era o energúmeno, que rolava na casa, bradando, chorando como uma criança, infeliz deveras, por esse triste amor do outono. O pobre diabo, feito de devaneio, indolência e afetação, era, em substância, tão desgraçado como Otelo, e teve um desfecho mais cruel. (Assis, 2004, p. 166, grifo meu).

Trata-se de uma história em que o personagem consegue apenas agir dentro dos padrões sociais esperados, dentro de uma normalidade, atravessada pela gentileza. Ele não rompe com seu acanhamento. Apenas na esfera íntima do quarto torna-se um "energúmeno", explode, liberta sua imaginação e consegue realizar grandes ações, sem sair do lugar. Machado de Assis explora o duplo sentido da palavra, do homem possuído, possuído pela dor, e do homem desprovido de capacidade de ação. O confronto vivido com Queirós ou seu amor por Joaninha nem chegaram a existir fora dele enquanto ação, pois nenhum deles soube das motivações de Inácio. Não se revelaram nem a raiva que sentia por Queirós, nem o desejo amoroso por 
Joaninha. Era um universo interior, onírico, que passava para ação. Ao final, Rangel se tornou padrinho de casamento de Joaninha e Queirós. A conciliação existia, mas era reservada apenas para os outros.

\section{Os fios desfeitos do épico}

Ao atentar para a prosa machadiana (crônica, romance e conto), escrita a partir de meados dos anos de 1870, é possível observar o quanto a narrativa machadiana é tributária da releitura atenta e crítica da tradição épica. Ainda nos anos de 1860, Machado de Assis, enquanto crítico, interroga a presença do poema épico no meio da prosa circundante. Advoga sua transformação histórica, mas mantém firme a convicção de sua possibilidade.

Na poesia, em Americanas (1875), Machado de Assis parece testar a possibilidade da poesia épica, transformada historicamente, mas ainda possível de ser feita com seriedade. Neste livro, ele estabelece um diálogo com a tradição épica ocidental para lidar com a matéria brasileira. Poderíamos dizer que há uma tentativa de elevação épica que se afasta do jogo imaginativo da crônica (na imprensa), de sua incursão no romance e no conto. No patamar elevado das grandes obras literárias, a história brasileira ganharia, assim, feição elevada nos gestos de resistência de personagens anônimos da crônica jesuítica, por exemplo. Isso aparece na poesia, de tom elevado e sério, na figura de Potira, uma contribuição machadiana para a figuração dos índios na tradição épica brasileira. Ao dar nome para uma pessoa anônima e brevemente citada na crônica histórica, e ao deslocar da dimensão religiosa do jesuíta, o narrador concentra-se na tensão humana de Potira. Ela abandonou sua tribo, casou-se com um homem branco, morava no Rio de Janeiro. Raptada pelo chefe tamoio, ela se mantém fiel a seu marido e se sacrifica por seu ideal.

Na prosa, no entanto, também nos anos de 1870, mas principalmente depois de 1880, quando aparece algo próximo de um gesto heroico, ele vem atravessado pela ironia de um narrador que se coloca como superior aos pobres, às mulheres, aos escravos. São três esferas distintas, cada uma formada com suas próprias regras. Na crônica, através de um pseudônimo, a invocação dos traços mais comuns, ou mesmo acessórios, do épico, torna reconhecível a distância dos tipos cotidianos em relação à elevação necessária. O herói de nossa época seria Rocambole, que vem da delegacia e do folhetim para representar a sua época. O dinheiro está no centro, no caso dos vereadores corruptos e na aparente celebração da honestidade de Abranches. O astuto Ulisses se reverte em "herói" da probidade. Nestes casos, o épico é usado no discurso do narrador cronista para revelar a mediocridade do cotidiano urbano.

Machado de Assis, principalmente a partir dos anos de 1870, experimenta as possibilidades do conto moderno. O conto se emancipa da tradição, não é mais narrativa exemplar, nem demonstração moral. Trata-se de uma narrativa curta publicada pela imprensa (revistas ou jornais), numa tensão entre obra de arte e produção para entretenimento, que é expressão indireta da relação entre arte (produção autônoma) e mercadoria (publicação voltada para o comércio). É nesse âmbito que a incorporação do épico ganha sentido irônico. Machado de Assis restringe o épico às marcas discursivas, usadas por seus narradores intrusos para contarem histórias triviais. A abertura de "Capítulo dos chapéus" é exemplar desse descompasso entre o discurso do narrador ("Musa, canta o despeito de Mariana") e a matéria narrada (a esposa que pede ao marido que troque seu chapéu). Vemos a distância entre o discurso elevado do narrador, próprio do épico, e a vida prosaica dos personagens. A indignidade da matéria cotidiana não tem potência para se tornar assunto épico.

Neste artigo, não foi objetivo dar ênfase para a análise do romance machadiano. Ainda assim importa colocar que, enquanto totalidade complexa, parece a súmula da incorporação irônica do épico. Temos a totalidade extensiva, mas a fragmentação e a descontinuidade das 
ações de um Brás Cubas esvaziam a dimensão épica. O discurso do narrador não alcança a seriedade que confira dignidade à matéria narrada.

Cabe perguntar, então, mesmo que seja em forma negativa, pela contribuição da reflexão sobre o épico para entender a obra de Machado de Assis.

A forma, não apenas da poesia moderna, mas também de outros gêneros literários do século que se escoou desde então, é dificilmente imaginável sem As flores do mal; a marca da influência de Baudelaire pode ser encontrada tanto em Gide, Proust, Joyce e Thomas Mann, como em Rimbaud, Mallarmé, Rilke e Eliot. O estilo de Baudelaire, a mistura que tentamos descrever, continua tão vivo quanto antes. (Auerbach, 2007, grifo meu).

Quando passamos da crítica para a criação literária, vemos que a prosa machadiana (crônica, conto e romance) incorpora não apenas ironicamente o épico, para mostrar sua inviabilidade na modernidade ou no Brasil. O épico se torna um elemento de tensão discursiva entre esforço de elevação discursiva do narrador e precariedade da matéria narrada. Este discurso cai no vazio, seja pelo prosaísmo do troco miúdo da cena (em Abranches ou o despeito de Mariana), seja pelo caráter rebaixado do cotidiano brasileiro, ou ainda pela incapacidade de ação de um personagem.

Assim, a reflexão sobre o épico ajuda a entender a busca de uma forma adequada para narrar a matéria brasileira. Machado de Assis, num gesto moderno, escolheu a mistura entre elevação discursiva e rebaixamento da matéria narrada. Essa mistura, no entanto, é tensionada a cada momento pelo gesto brasileiro, do narrador de elite, que tenta se desvencilhar da matéria baixa. Deste modo, o discurso do narrador demonstra seu conhecimento da tradição épica ocidental. Esse domínio da tradição literária letrada, em vez de elevar, vai rebaixar ainda mais o comerciante comum (Sriber), o funcionário inerte (Rangel) ou a esposa acomodada (Mariana). No meio da prosa machadiana, um discurso épico, mais do que se misturar à matéria narrada, acentua o abismo entre o universo elevado do narrador e a precariedade da realidade representada.

\section{REFERÊNCIAS}

ASSIS, Joaquim Maria Machado de. Obra completa. Rio de Janeiro: Nova Aguilar, 2008.v. 3-4.

ASSIS, Joaquim Maria Machado de. Correspondência de Machado de Assis, tomo 1: 1860-1869. Apresentação, coordenação e orientação de Sergio Paulo Rouanet; organização, Irene Moutinho, Sílvia Eleutério. Rio de Janeiro: ABL, 2008. (Afrânio Peixoto, 84).

ASSIS, Joaquim Maria Machado de. História de quinze dias. Organização, introdução e notas: Leonardo Pereira. Campinas: Editora da UNICAMP, 2008.

ASSIS, Joaquim Maria Machado de. Balas de estalo de Machado de Assis. Organização e notas de Heloísa de Luca. São Paulo: Annablume, 1998.

ASSIS, Joaquim Maria Machado de. Histórias sem data. Edição de Hélio Guimarães. São Paulo: Martins Fontes, 2004.

CHALHOUB, Sidney; NEVES; Margarida S.; PEREIRA, Leonardo A. M., orgs. História em cousas miúdas: capítulos de História Social da crônica no Brasil. Campinas: Ed. da Unicamp, 2005.

AUERBACH, Erich. Ensaios de literatura ocidental. Trad. Samuel Titã Jr. e José M. M. de Macedo. São Paulo: Duas Cidades; Editora 34, 2007. 
AUERBACH, Erich. Mimesis. 2. edição. São Paulo: Perspectiva, 1987.

ADORNO, Theodor. Anotações sobre Kafka. In: Prismas: crítica cultural e sociedade. Trad. Augustin Wernet e Jorge Almeida. São Paulo: Ática, 1998.

ADORNO, Theodor. Sobre a ingenuidade épica; Posição do narrador no romance contemporâneo. In: . Notas de literatura I. Trad. Jorge Almeida. São Paulo: Duas Cidades; Ed. 34, 2003.

BARTON, Anna. Nineteenth-Century Poetry and Liberal Thought: forms of freedom. Sheffield: Palgrave, Macmilian, 2017.

BENJAMIN, Walter. O narrador: considerações sobre a obra de Nikolai Leskov. In: __. Magia e técnica, arte e política: ensaios sobre literatura e história da cultura. Trad. Sérgio P. Rouanet. São Paulo: Brasiliense, 1994.

BLANTON, C. D. Epic Negation: The Dialectical Poetics of Late Modernism. New York: Oxford University Press, 2006.

GLEDSON, John; GRANJA, Lúcia. Introdução. In: ASSIS, Joaquim Maria Machado de. Notas semanais. Organização, introdução e notas: John Gledson e Lúcia Granja. Campinas: Editora da UNICAMP, 2009.

HEGEL, Georg W. Friederich. Curso de Estética. Trad. Marco Aurélio Werle, Oliver Tolle. São Paulo: EdUSP, 2004. v. 4.

LUKÁCS, Georg. Ensaios sobre literatura. Rio de Janeiro: Civilização Brasileira, 1968.

LUKÁCS, Georg. Teoria do romance: um ensaio histórico-filosófico sobre as formas da grande épica. Trad. J. Marcos M. de Macedo. São Paulo: Duas Cidades; Ed. 34, 2000.

MORETTI, Franco. Modern epic: The World-System form Goethe to Garcia Marquez. Trad. Quintin Hoare. Londres: Verso, 1994.

MORETTI, Franco. The Novel: Forms and Themes. New Jersey: Princeton University Press, 2006.

MORETTI, Franco. The Novel: History, Geography and Culture. New Jersey: Princeton University Press, 2006.

RAMOS, Ana Flávia Cernic. As máscaras de Lélio: Ficção e realidade nas "Balas de estalo" de Machado de Assis. Tese (doutorado em história) - Universidade de Campinas, Campinas, 2010.

ROSENFELD, Anatol. O teatro épico. 3. ed. São Paulo: Perspectiva, 1994.

SÁ REGO, Enylton J. de. O calundu e a panacéia: Machado de Assis, a sátira menipéia e a tradição luciânica. Rio de Janeiro: Forense Universitária, 1989.

SCHWARZ, Roberto. Martinha versus Lucrécia: ensaios e entrevistas. São Paulo: Companhia das Letras, 2012. 
VERNANT, Jean-Pierre. A bela morte e o cadáver ultrajado. Trad. Elisa Kossovicth e João A. Hansen. Discurso, São Paulo, n. 9, 1978, p. 31-62.

ZILBERMAN, Regina. Brás Cubas Autor, Machado de Assis Leitor. Ponta Grossa: Editora UEPG, 2012.

VIRGÍlIO. Eneida. 2 Ed. Bilingue. Trad. Carlos Alberto Nunes. Organização, apresentação e notas de João A. Oliva Neto. São Paulo: Editora 34, 2016.

Antônio Marcos Vieira Sanseverino - Doutor em Letras (PUCRS), é professor associado na UFRGS e pesquisador do CNPq, com pós-doutorado na Brown University. É autor de "A presença de escravos em alguns contos de Machado de Assis", "Esquisitas e desmioladas: o narrador, o adultério e a representação feminina no conto machadiano" e "Cantos Ocidentais (1880), a poesia machadiana na Revista Brasileira", entre outras publicações. É membro da equipe de pesquisadores do projeto Discurso da épica nas culturas lusófonas do século XIXProbral Capes/DAAD 2018-2021. https://orcid.org/0000-0001-6085-0881.

Submetido em 12/01/2020

Aceito em 20/03/2020 